\title{
Joint Relationship in Fishery Affairs between the European Union and Mexico
}

\author{
Hidalgo Gallardo Amada, Hidalgo Gallardo Ruth Leticia, Cruz Cruz Mario, \\ Moreno Islas Heriberto, Avila Hidalgo Sofía Elizabeth
}

Department of Economic and Management Science, University of Hidalgo State, Pachuca, México

Email: misshidalgo2009@yahoo.com.mx,ruth.757@hotmail.com

How to cite this paper: Amada, H.G., Leticia, H.G.R., Mario, C.C., Heriberto, M.I. and Elizabeth, A.H.S. (2018) Joint Relationship in Fishery Affairs between the European Union and Mexico. Journal of Human Resource and Sustainability Studies, 6, 92-107.

https://doi.org/10.4236/jhrss.2018.61029

Received: January 14, 2018

Accepted: March 23, 2018

Published: March 26, 2018

Copyright (c) 2018 by authors and Scientific Research Publishing Inc. This work is licensed under the Creative Commons Attribution International License (CC BY 4.0).

http://creativecommons.org/licenses/by/4.0/ (c) (i) Open Access

\begin{abstract}
Global warming, the greenhouse effect and the weather are part of the environmental damage that currently threatens our planet to the human and ecosystems. Activities seriously affected include fishing, item that has to be respected and restructured around the world even it is required to maintain food security. For the European Union and Mexico, this activity is important since they have coastlines and must care the resource to be a relevant product for their communities, on the other hand, fisheries restructuring is an international guideline which places these two parties on a problem of sustainability, mainly for Europeans that apply all their strategies to achieve the resource and attend the demand of their community. This study has the purpose to analyze the negotiations between European Union and Mexico in the fisheries sector, the degree of interdependence, which has reached in this activity derived from the natural resource requirements. This research has been elaborated in a descriptive analytical and qualitative process based on the theories of interdependence, vulnerability and sensitivity to which the European Union and Mexico are submitted according to international policies expressed in national policies in European Union and Mexico. Therefore, the European Union and Mexico adjust their requirements on natural resource through treaties and commercial fisheries agreements in order to meet the needs of their communities. However, international fisheries restructuring conditions still denote irregularities which have to be reviewed in a hard regulatory in a globalization order.
\end{abstract}

\section{Keywords}

Fisheries Restructuring, Commercial Strategies, EU, Mexico 


\section{Introduction}

The International Community (IC) has raised the fishing problem as vulnerable on food security and invited to attend it immediately, through restructuring the fishing activity to achieve a safe fishing. In consequence to this international guideline is convenient for States file trade agreements as means for supplying national and international markets and in this way, coping with fishing restructuring. Currently, the oceans are facing two scenarios: pollution for industrial and household waste and warming seas, these processes exercise detrimental effects for the marine natural resource, either in geographic changes, mutations or, in the worst case, death.

The UNO and other instances as the Food and Agriculture Organization of the United Nations (FAO) and the United Nations Conference on Trade and Development (UNCTD), focus the trend of the restructuring fishing activity on a sustainability way and with international normativity conveyed into domestic policies of the States.

For the States, the fishing restructuring represents the establishment of an optimum administration of the resource with regard to supply and distribution. This process was sealed in the world summit of 2002, which compiles the government's commitment to keep or reestablish fishing population to a maximum sustainable output. Derived from the resources depletion, this objective was stipulated as emergent, that is, to be accomplished by 2015 however, the process has been slowly showing imbalances of application by the States.

According to Costello et al. (2012) [1], the seas capacity to satisfy the demand is uncertain, because of the fishing ground or the fishing population extinction. For FAO (2003) [2], the aim is to face the demand by 2030 approximately of 150 million tons per year, when the sustainable annual capture only provides $80 \mathrm{mil}$ lion tons. Likewise, the OECD (2012) [3], reflects FAO data that indicate an overexploitation of $17 \%$ of the world fishing, depletion of $7 \%$ and only $1 \%$ is recovered by depletion.

Before this problem, it has been developed this research designed in a case descriptive qualitative analytical in a period of 2013-2015 with the purpose of analyzing business strategies used by developed countries with the objective of obtaining the fishing resources through practices influential in developing countries, without generating retribution on technologies or technical training which generates a complex interdependence in fisheries restructuring, the scarcity of the product, fishing needs as well as on compliance of international guidelines to the evolution and practice of such activity.

The work is based on the complex interdependence theory, concept acquired by the problem presented by the accelerated interconnection of the economies and negotiations derived by fishing activities. Likewise, the ideology of Katzenteisn (1976) [4], Dahl (1957) [5], Tucker (1977) [6] and Holsti (2006) [7] are added, commenting additional subjects about the sensibility and vulnerability that the States face, derived from foreign policies; in this case, fishing restruc- 
turing must be applicable to domestic policies, looking for food security.

This analysis is focused on the actions of the European Union and Mexico, both with fishing maritime littorals, with own needs of supply and distribution, different geographic-politic status and with interests of stipulate trade relations under fishing treaties and agreements. Through the analysis is perceived that, both parties have signed agreements that are more beneficial to the European Union, noticing a European approach of fishing policies, tactics and partnerships that only bind the Mexican fishing as reinforcement for their fishing necessities. While the agreements are profiled and the strategies are adjusted, the world demand of fish and seafood continue in a constant increase while the littorals are in decrease which foresees the fishing fall along with food insecurity.

It is relevant to point out the main aspects for the EU on fishing activity, on one hand the variety of negotiations with the fishing agencies, on the other hand to consider the importance of Spain for the community and, finally, their strategy of the establishment of agreements with third-party; all this platform with a view to confront the fishing insecurity challenge in the European Union.

The EU, in attention to the international policies of environmental protection, transfers them into their domestic ones. This includes the marine resource preservation that derives into the activity restructuring. The European tactics to maintain their leadership in captures and consumption of the resource is: retention and contribution in Regional Fisheries Managements Organizations (RFMOs), ${ }^{1}$ which impacts on the control and management of the resources at the global level.

During the construction of strategies to address and handle the evolution and world fishing policies, the EU consolidates partnerships with third-party for supply and distribution. In accordance to Eur Lex (2014) [8], the Union is looking to establish and guarantee their resources and to limit the gap of the affected regions by the domestic fishing policies application due to international normativity. ${ }^{2}$

Similarly the EU organizes clusters, ${ }^{3}$ according to the Spanish Network of Parks and Clusters (2013) [9], these are fundamental tools of support for direct foreign investment (DFI), supply of communitarian fish, development cooperation, employment creation and wealth in third countries where they develop their activity and have bilateral agreements.

Dayton-Johnson et al. (2006) [10], indicates that, the EU establishes fishing ${ }^{1}$ RFMo: (observer in 11 and 6 as a member).

${ }^{2}$ Eur-lex: Repertory of Fishing International Agreements EU. Agreements about the Atlantic tuna, dolphins and highly migrant fishes preservation on the central and western pacific ocean; fishing vessels management on high seas; living resources on the Baltic Sea and on the Danish straits; cooperation of the North-eastern and North-west Atlantic fishing grounds; and salmon conservation.

${ }^{3}$ Clusters: The Cluster of Fishing Companies in Third Countries is an association that brings together the European investors interests on the fishing sector of third countries, what used to be joint mixed enterprises. Currently, these investors come from Spain, Italy and Portugal, and their investments are based in third countries different from the EU ones, for what it is about societies under the law of those countries. The General Secretariat of the Sea of the environmental and rural and marine environment Ministry of the Government of Spain participates as protective partner. 
agreements with third countries to gain access to surplus stocks in coastal waters of developing countries (DC). The risk represented for developing countries is to turn into a utilitarian income without ensuring the sustainability of the fishing stock in a long-term as well as the life style of the local artisanal fishermen. Therefore it is so relevant to the European Union support agreements with third parties and keeps amounts of natural resource that is demanded for his community.

For the above mentioned, Mexico is an important State worldwide for their great capability in coastlines and exclusive economic zone (EEZ) that outlines it potential yields in fishing resources also in food security. The European projection in Mexico is urgent because of the communitarian fishing unbalance, which generates domestic pressure since the slowing down programs and projects applied in the community by captures that have not given the expected results. This fishing crisis has passes on other economic problems such as; unemployment, food unbalances and problems with third countries.

As it was mentioned before, Spain is a important State to the EU in the following areas: due to its fishing vocation and path, is the third supply country of the European community; it is also the entrance of the continent; and because of its historical-economic relation with other countries, with whom have been realized relevant fishing agreements to the community. In this context it is important to initiate with the existing relation between Spain and Mexico and in consequence with the EU.

\section{Methodology}

As a consequence of the economic free trade policy, two main aspects in the world are developed; on one hand, the accelerated industrialization that ends with catastrophic environmental effects reflected in natural resources and, on the other hand, the economic dependence of the States. This dynamic offers new survey lines within the International Relations in which authors like Robert Keohane and Joseph Nye (1977) [11] are already pronouncing for the complex interdependence theory, concept acquired because of the problem presented by the economies interconnection. Likewise the ideology of Katzenteisn (1976) [4], Dahl (1957) [5], Tucker (1977) [6] and Holsti (2006) [7] are added, commenting additional subjects about the sensibility and vulnerability that the States face derived from foreign policies applicable on their domestic policies.

Therefore, this investigation is submitted to those doctrines which involve the complexity of the international resolutions regarding the vulnerability in the emergency to attend the climate change phenomena, greenhouse effect and marine resource through international policies of restructuring the fishing activity. By the other hand, the sensibility shown in the States because of the transfer of the foreign policies into their domestic ones as a forcible means and control of the natural resource.

To be able to observe this inertia, is considered to analyze the European Union and Mexico for their particularities on the fishing sector, the agreed negotia- 
tions and the extent of interdependence reached on fishing activity. For that purpose it has been considered information from Public International Law (PIL), the United Nations Organization (UNO), the United Nations Framework Convention on Climate Change (UNFCCC), the Regional Fisheries Management Organizations (RFMOs), the World Trade Organization (WTO) as well as from other authors studying the subject. In contrast is corroborated the information with own data of government agencies of the European Union and Mexico in which it is revealed the application of the international normativity on their government guidelines, the supporting programs on restructuring as well as the solutions and results of the fishing agreements.

\section{1) Fishing relation between Spain-Mexico}

Cifuentes et al. (1997) [12] indicate that since the conquest, the Spanish find a very organized production of white fish, spirulina algae and fisheries, as well as pre-Hispanic societies that disposed a secure navigation in the rivers and seas, with a overshadowed progress by the conquest.

In the 20th century, Spain had to adjust to the requirements planted by third-party, both in the international and within the communitarian space. The civil war (1936-1939) had a negative impact in fleet and captures; from 1977 to 1982 the sector was more harmed with the adoption of the 200 miles as the EEZ by the majority of countries.

For Nayma (2006) [13], the Spanish position through the centuries is due to, not because of its own fishing grounds, but because of the increase in outreach, which promote growth. During the seventies, Spain reached its high fishing record with $1.350 .000 \mathrm{~m} / \mathrm{t}$; however, the EEZ adoption and the EU membership has positioned it in a decrease of captures.

Likely Mera, T., et al. (2001) [14] indicate that, despite the unbalances in Spain during the seventies, the trade relation with Mexico reaches a "15.5\%" of the total (bilateral) trading value among companies with high tariff protection. The Spanish exportation to the Mexican economy is looking for raw materials, natural resources such as financial activities, non metallic minerals and fisheries.

According to Martinez D'Meza (1979) [15], joint companies in the fishing sector (Mexican-foreigner) was launched with an initial group of 12 companies (6 Spanish, 3 Americans, 2 Korean and 1 Japanese). It is followed by new projects with the intention to catch knowledge, technical competence and investment. It is worth to mention that Mexico already built the adequate infrastructure to operate vessels with a high draft of 7 meters.

In 1970 Mexico diversified its activity to catch anchoveta and finfish species, also relevant for the Mexican fishmeal and consumption, but these species were overexploited caused by foreigners fishing out of the 12 miles limit regulation. Medina (1976) [16], points out that, a consequence of the fishing of these species by foreigners is that, the Inter-American Development Bank (IDB) will grant funding to enlarge the Mexican fleet, provide resource applied in the construction of 236 fishing vessels and another two under studies. In the seventies, Germany participated with Mexico in a fishing program in the Pacific Ocean send- 
ing German vessels; one of each is specifically for oceanographic investigation called "the Humboldt".

Doode (1990), [17] says that Mexico, during the seventies and eighties, achieved an important value in the field, increasing the capture but generated the exploitation of the species. The sardine is located in the Gulf of California with a high production, capture activity producing 20,000 tons of capture that in the eighties reached almost half of millions of tones occupying a significant amount of the country's total economic value.

Due to the great exploitation of the specie, destined to supply both the reduced and the avian industry, the sardine was on risk of extinction. The Mexican fleet, which on that time captures sardines in the pacific with purse seine, adopted new technologies in net tools and instruments which permitted to initiate a reordering of captures.

It is worth to mention the incidental fishing of hooting's, which in the seventies were of sport fishing, turning into a commercial fishing by the end of the eighties. Until then, they can only be fished by Mexican vessels 50 miles away, but the beginning of its commercialization occasioned that foreigner vessels obtain Mexican flag to continue exploiting species such as swordfish and striped marlin in the Pacific, particularly in Cabo San Lucas (Sosa, 1998) [18].

Macias et al. (1994) [19] argue that, because of the climate changes, this specie tends to change its geographical position, moving to the north towards the south pacific littoral in Manzanillo, forcing the vessels located in Ensenada to move to this littoral.

This phenomenon experienced by Mexico is a problem on their coastlines, therefore it only third party access is allowed in cases where there are surpluses of resources and that they may not be exploited by the Mexican Government, as a result of this provision arise ventures of catches of tuna and shark.

In the light of this context, Mexico signed its first agreement with Spain in 1977 based on mutual cooperation, reinforcing trade ties and providing the position of most favored nation (MFN). This agreement entered into force in 1978 creating other negotiations mentioned in Table 1 (Ministry of Foreign Affairs, 2013) [20].

Table 1. Treaties and agreements between Spain-Mexico.

\begin{tabular}{ll}
\hline Year & \multicolumn{1}{c}{ Conclusive documents of negotiation } \\
\hline 1977 & Agreement of Economic and Commercial Cooperation with Spain \\
1989 & $\begin{array}{l}\text { General Treaty of Cooperation and Friendship between Mexico and the Spanish } \\
\text { Kingdom }\end{array}$ \\
& $\begin{array}{l}\text { Technic Annex of the Cooperation Agreement in Agriculture among } \\
2005\end{array}$ \\
& SAGARPA-Mexico and MAPA Spanish Kingdom \\
& Memorandum of Understanding in Agricultural, Rural, Fishing and Food mat- \\
& ters.
\end{tabular}

Source: Own elaboration with data of the SRE and SAGARPA-Mexico. 
It is worth to mention that, in the agreement of mutual cooperation, there are guidelines of economic and commercial cooperation, indicated in the articles 8 and 9 which regulate the maritime trade relations, the operations of vessels in ports and specify favorable actions in basic sectors such as fishing and aquaculture. The visible result is the Mexican-Hispanic joint companies, giving way to an undefined format respecting each countries domestic law. It is constituted a Mexican-Spanish sub-commission of cooperation to inform the enforcement of the program and to maintain permanent contact with the joint Commission.

This agreement has experienced uncertainty due to problems in the Pacific littoral, the RFMO Inter-American Tropical Tuna Commission (IATTC) ${ }^{4}$, determined that the capture rates decrease during 1978-1981 because of the efforts concentration in the fishing of small fishes and be exacerbated by the event of "El Niño" in 1982-1983, causing less vulnerability of the fishes to be captured (IATTC, 2011) [21].

Santinelli (2009) [22] points out that in the eighties, the Mexican government supported the fishing sector with resources precedent of the Guarantee Funds (FOPESCA) destined to support low income fishermen. Alcalá (2003) [23] indicates that, the public investment is decisive to the development and growth of the sector in Mexico, since the programs and plans are determined in the national development plans. At this time, the Mexican production rates have increased, reporting figures of $850.5 \mathrm{~m} / \mathrm{t}$ in the seventies, $1364 \mathrm{~m} / \mathrm{t}$ in the eighties and nineties, despite the changes suffered, the production was maintained between the $1219.4 \mathrm{t} / \mathrm{m}$.

Spain is annexed in the EU in 1986, change that led the Spanish government to manage their negotiations via the EU adapted to its global interests. These effects of integration provoke changes into the Spanish fleet, since the EU determines that this fishing is important not only for Spain, but for all the European Community. The follow-up of the negotiations Spain-Mexico, under the General Treaty of 1989, locate the links in a historic, politic, economic, scientific and technologic dimension that encourage the approach and progress of both of them. This treaty ratifies the continuity of the projects and creates the Binational Commission to lead notifications and negotiations (Ministry of the Interior, 2012) [24].

Similarly, is registered the Spanish cooperation for the Mexican economy modernization, the mechanisms for Direct Foreign Investment (DFI), with special mention to SMEs, tourism, programs of industrial and technologic modernization, natural resources and environmental management (Official Journal of the Federation, 1992) [25]. In 1996 the Joint Fund of Technical and Scientific Cooperation (FMCTC).

${ }^{4}$ RMFO-IATTC: The IATTC support is based into offer information about the register of vessels, authorized and unknown, parked in the littoral by seasons exercising illegal fishing, vessels with different flag of its nationality that provokes the overexploitation of the littoral. Ibidem p. 12 Also it can be seen in the web site of the Commission to verify the authorized and do not authorized vessels https://www.iattc.org//Previous-IUU-Vessel-Lists.htm 
While it is true, the bilateral contractual relation is developed in management but is presented the lack of following, low participation in technical issues of the projects and lack of presence of Spanish specialists with an enough intensity and frequency. The proposal is to coordinate formal patterns between Spanish agents, as governmental organisms (NGO), autonomic communities (CCAA) and universities able to capitalize the advantages of the Spanish cooperation in Mexico.

\section{2) Fishing Relation between EU-Mexico}

For Carrillo (2004) [26], the period 1989-2005, Mexico and Spain attend processes of liberalization, increment of economic integration, financial markets and level of interdependence. These are reflected in the Global Agreement of 1997, of fourth generation, which already associate the EU and Mexico. For Velázquez and Dominguez (2008) [27], these new agreements institutionalize the politic dialogue and strengthen the economic relations through bilateral liberalization.

While the agreement is signed in the frame of Free Trade Agreement European Union-Mexico (TLCUEM), a very specify aspect take importance within the tuna commerce between Mexico and the United States of America (USA), relating to the dolphins protection (USA law for this specie); USA, pressured by the American tuna industry and ecologist groups, initiate an attachment against Mexican tuna (La Crónica, 2013) [28]. The USA confirmed to the GATT the continue attachment, turning into a trial by fire to the strengthen of the new alliance with Europe, and the support of other countries (WTO, 2015) [29].

To this regard, Sberro, S. (2004) [30], indicates that tuna penalties imposed by USA against Mexico were spread towards all the countries obtaining the Mexican product. This disposition was clearly directed against the European negotiations, Spain defending the interests of its industry; maintain a tariff of the $23 \%$ on the imports of Mexican tuna.

By 2002, Mexico reached to negotiate with Italy, arguing that tuna is predator for dolphins (El Mundo, 2009) [31], the strategy served to introduce its new products on the European market. This example is symptomatic of the dynamic with Europe, goes beyond the strictly commercial bond and offers, from the

\footnotetext{
${ }^{5}$ Agreements between generations: kind of agreement, under the Treaty of Rome, of cooperation and development. Through the contemporary International Public Law and the United Nations instruments with a dominant action towards trade. The agreements of first generation (1971-1975) with the European Community are purely commercial and are settled with Argentina, Uruguay, Brazil and Mexico. It is a bi-regional relationship in the EU-LA field; the second-generation agreements (1980-1985) subscribed with Central America, the Andean Pact and Brazil highlight the business cooperation. The third generation agreements (1990-1993) distinguished by their democracy-development axis, signing bilateral or sub-regional agreements with Central America and the Andean Pact. The fourth generation agreements (1995 onwards) with the aim to create free trade zones and politic cooperation, ambitious and most far-reaching, attending to the LA region to spread in other areas. See works of Del Arenal, C. Cooperation Agreements between the European Union and Latin America (1991-1997); evolution, balance and perspective, Ayuso, A. Cooperation for the European Union development in Latin America. Crespo, J. European Union-Latin America: Two Regions one Destiny.
} 
opening of the European market, a real long-term alternative to the exclusive relation with USA.

The Official Journal of the European Union (2000) [32] indicates on section 10 article 10 the regulation of agriculture and fishing products, indicating the trade liberalization process by 2011 and the possibility to concrete by 2012 a tariff quota with a special treatment for tuna loins. There are stipulated rules of origin that products must accomplish during the period 2009-2014 and particular conditions of the importation of fishing and aquaculture products from Mexico are fixed (Ministry of Economy, 2010) [33]. In the same way, fishing health certificates are fixed from Mexico to the EU, except in the case of some species, designed and reviewed certificates in 2005 (Official Journal of European Communities, 2001) [34].

By the other hand, new cooperation techniques are concreted, simplifying the tariff regime, the technique assistance and cooperation for the environmental care, it is distinguished the section that regulates the sign of sectorial agreements on environment and natural resources (Official Journal of the Federation, 2000) [35].

The cooperation on the fishing sector, contemplates the socioeconomic importance of the activity for both parties and to be needed, the implementation of a sectorial agreement in accordance with the respective legislations. On fishing products there were established four tax relief deadlines and a waiting list for sensible products, the Mexican canned tuna obtain priority access (Chamber of Deputies, 2000) [36].

Similarly, the elimination of the customs tariff of agriculture and fishing products is granted, in this case for species of fishes and crustacean, selfish and other aquatic invertebrates. The tax relief is gradual on importations for both parties, in reserve left the quota and tariff extension if the circumstances require them. These activities are established in periods of 3 years, covering both the procedure verification and the quota extensions or tariff restriction (Silvetti, 2001) [37].

Furthermore the creation of specify programs in economic, commercial, scientific-technic aspects is articulated, as well as the participation of the private sector in the fishing development. For the programs development it is agreed the financial support between EU-Mexico, under the presentation of projects on services, supply and work, stipulating that the resources provided by the EU are applicable directly to the projects, assuming that all the resources destined to this cooperation will be adjudicated by the European Investment Bank (EIB).

Bolt (2008) [38] points out that, the European Direct Foreign Investment in Mexico during 1994-1999 on the agricultural, forestry and fishery was of 2339.78 md and from 2000 to 2007 of 5,847.61 md. The European participation has been from Spain (0.20\%), Netherlands (5.20\%), United Kingdom (1.90\%), France (3.30\%) and Germany (0.60\%). Spain, particularly, has provided funding to the bank sector. 
For what, it is may consider that both the TLCUEM and the APRPI, ${ }^{6}$ guarantee investments in the trade of agricultural products, especially in the fishing one, in any case it is intended that the investment in this field tends to increase o support development and internationalization.

In parallel to the negotiations between UE and Mexico, specify bilateral agreements are carried out, such as the Agro-food Technical Annex in 2005 and an Understanding Memorandum in Agricultural matters in 2012. Regarding the Technical Annex 2005-2007, the SAGARPA and MAPA (2002) [39] develop the agreement of cooperation in agricultural issues and specify programs. This is beneficial for the business sector and cooperation; for fish producers and to promote the commercialization of products such as tuna and squid.

Relating to the Memorandum, the negotiation come from two previous pacts about transferring experiences, technical and technology and protection of the environment for a sustainable development, suited to each national legislation (Ministry of Agriculture, Food and Environment of Mexico, 2012) [40]. This memorandum has a very specific characteristic on its ninth clause, where it is exposed that the document is not legally binding and it will not be subject to the International Public Law. It also argues that any controversy will be resolved in the Commission with the possibility to be modified through the attached letter duly authorized by them. With these guidelines it is granted the doubt regarding the legality of the document and the fishing and aquaculture practice.

In addition to this record, the European Parliament (2008) [41] indicates that it is concluded an EU-Mexico Strategic Association, involving topics of environment, energy, biodiversity, climate change, natural disasters and marine resources overexploitation, which determine that the fishing issue is a relevant topic for the EU and that it is imminent its regulation with the aim to ensure the natural resource in third-party littorals.

However and after knowing all this type of agreements and cooperation, it is observed that, despite having signed agreements and key strategies on fishing infrastructure as well as alliances with third-party, illegal fishing in Mexico is experienced. The National Chamber of Industrial Fishing (CANAINPESCA) in many occasions has reported European vessels under flag of convenience, fishing in the area with highly predator fishing gears or with devices to accumulate fishes $\mathrm{FAD}^{7}$ which is taking the tuna fishery to a critical situation (Greenpeace,

\footnotetext{
${ }^{6}$ APRPI: Agreements of Promotion and Reciprocal Protection of Investments; bilateral agreements with the aim to protect under the International Public Law the investments realized by the investors of each signatory State. This allows reducing the politic and legal uncertainty that is usually perceived in the operation of programs executed by companies abroad. The period of effectiveness is defined by each signatory party, the APRPI are often elaborated with a set of clauses and competent measures on legal and politic security. See Illescas, J., Treaties of investment protection and its utility for Spanish investors in Latin America. Diez Hochleitner J. International Arbitration as a protection way for Foreigner Investors in APRPI.

${ }^{7} \mathrm{FAD}$ fishing (Fish Aggregating Device): fish aggregating system, is a net structure of large dimensions combined with purse seine, it is thrown to the sea to draw the resource; species such as tuna, whales and turtles are captured. There is no time to divide them at the time of freezing and canned and they mixed. This kind of process is unsustainable for fishing. It can also be seen in https://www.greenpeace.org/international/ the zones of most FAD in the world.
} 
2014) [42].

The majority of these pirate vessels are Spanish, the "Panama Tuna" case, who disrupt the sustainable management of fisheries for not respect quota, gear, methods, capture of juvenile tuna fish, marine turtles, sharks, swordfish and other commercial species discarded as waste. With the traditional method up to 75,000 fishes from diverse species can be captured, while with the FAD, the capture is up to 130 million (Este País, 2001) [43].

The $90 \%$ of the FAD fishing is of target species and incidental, which cause an impact on the marine ecosystems and is not sustainable. Mexico has reiterated its concern for this method, has proposed measures to reduce juvenile mortality since its size has diminished from $13.5 \mathrm{~kg}$ to $7.2 \mathrm{~kg}$. Furthermore it is recognized that these fishing fleet are highly subsidized and placed on Mexican domestic markets and abroad, causing detriment to Mexican fisheries. This pirate fishing affects the environment, natural resource, growth processes, domestic and foreign markets and, finally, Mexican littorals.

To this respect, Pearson, F. and Rochester, M. (2000) [44] is very accurate when he indicates that, even when the capitalist developed countries trade mostly between them, they strongly depend on the developing countries as an important source for its fishing importations and as markets for its exportations of elaborated products.

\section{Discussion}

In accordance with this analysis, the environmental phenomenon facing by our planet has been the fundamental problem of imbalance in human life and the loss of ecosystems, i.e., the harm to the environment has caused, droughts, melting, floods and hurricanes in different parts of the world issues that are reflected mainly in forests, agricultural and fishing which leads to a dilemma for food security. To address the problems in fisheries, the international community has generated a new order for fisheries restructuring at the global level in order to protect the production and capture in a sustainable way. These guidelines are directed towards the implementation of measures, mechanisms and strategies to care for natural resources under international regulations that must be contemplated by the international community; in this case Governments must implement the regulation in their internal policies.

According to such regulations applicable to internal policies, the strategy of fisheries restructuring, in the cases of Mexico and the EU, have been a challenge since they require the field to solve its domestic demand. It should consider that fishing negotiations with Mexico started since before that the EU be constituted, it would already have started commercial relations with Spain by fisheries agreements, which in some cases, do not exist legally binding, which was considered from 1970s and 1980s, since then Spain already have had this problem of weakness in fishing amounts, this trouble was increased with the EU. On the other hand, the EU is consolidated as a leader in the fishing industry because it 
requires the product since it faces difficulties in its productivity by: lack of stocks, stocks over exploited, species in extinction and restructuring of the sector. While the EU has well plotted strategies as the ORP, clusters or organization agreements with third parties, still have difficulties to achieve capture so, their proposal is to reduce exploitation in European waters against the opening of fisheries in waters of third countries.

The imbalance between the developed and developing countries in natural resources therefore it follows being a strong fight to get the resource, the case of Mexico observed that the Mexican coasts still have a fishery production that motivates the EU generate negotiations in the activity, but also Mexico must comply with international guidelines and must employ strategies for care which implies that, while agreements are signed not possible that developed countries lack the resources developed countries with this natural.

Currently the EU has established fishing trade agreements and clusters with Mexico since Mexican littorals have species and extensive biodiversity valued both by Spain and the EU. However, the Mexican government faces serious problems signing fishing agreements binding to international regulations, climate change affecting fishing, attention to the sector restructuring, surveillance, negotiation, normativity and monitoring agreements with the EU.

The Mexican negotiations regarding the use of its littorals by third countries are cautious and mid-term, at the moment there is no lease, the agreements are sporadic until 2012 and some do not have tight legal observation. The support to the fishing sector is planned under the generality and formalization of trade and association treaties, that is, sectorial agreements do not exist, for that negotiations are based on reviewable document, if they carry out, while the natural resource is obtained in littorals without retribution.

Within the Framework Agreement, regarding fishery products, general tax relief and priority access for Mexican canned tuna were agreed. This negotiation's strategy indicates the reinforcement of Mexican littorals towards European markets.

\section{Conclusions}

In accordance with the accelerated industrialization around the world over the past 5 decades has left its mark in the atmosphere; the high fuel consumption, population growth and pollution of the seas have affected the environment, to human life and natural resources, in particular fishing, which has put food security on alert. Due to this phenomenon, it was necessary for the international community apply regulations in fishery restructuring which affects the countries, in this case of analysis to the European Union and Mexico in its application of regulation as well as the fishing communities supply.

This relationship has been awarded to the topics about the vulnerability and sensitivity of international policies involved in the internal policies of the EU and Mexico, fisheries restructuring should be considered because of accelerated 
in the ecosystem damage, which will produce in the short term, neither rich countries nor the undeveloped may get the fishing resource.

Certainly, the EU as a world power and experience in the seas has employed their strategies to achieve the amount of fishing, although it remains dependent on third parties. This situation to EU and Mexico means a complex interdependence, since both require product but there is also the observation of specific organizations that oversee the global reordering and indicate time of fishing and amounts of capture, which EU and Mexico are under continuous observation of regulation.

Even though they have signed agreements, not only natural resources depend on the signed paper, it depends about respect to reproduction, of the seas and fish stocks, this topic will generate a balance with benefits of future generations.

On the other hand, the practical of EU maintains agreements to achieve fishing but not attends the requirements of Mexico as a country in development; EU could make transfer of technology or technical training to generate fishing reproduction. Actually international organizations are calling to the developed to provide for modernization of the undeveloped precisely to make their sectors promote.

According to the analysis, it is evident that fishing restructuring worldwide, is an action of respect to the resource since the observation of overexploitation, lack of closure, geographic changes, extinction and death caused by environmental damages. For the human being, it is a necessary activity for its livelihood but it puts forward the issue of food security.

The expectative for Mexico about the fishing issue is reflected in observable strategies towards the follow-up of international guidelines involved in domestic policies for sustainable improvement, attention to pollution by industrial and household wastes in the seas, elaboration and presentation of direct affordable programs and projects for fishing.

Furthermore, new plans and strategies are generated to restructure the activity and perform it in a sustainable way, in such case, respecting closures, avoiding juvenile species fishing, increasing efficiency and effectiveness in surveillance and attending the Mexican fishing demand. Similarly, the regulatory revision of the Framework Agreement for fishing, creates fishing agreements with utilitarian income, only if the sustainable fishing and the production allow it to create regulation for littoral exploitation with specific clauses in illegal and sustainable fishing, generate clauses to enforce penalties of illegal fishing, breach of agreements and breach of international normativity.

Finally, to share seas is synonym of responsibility for humanity, taking into account that, food security and marine ecosystems are in danger; fulfilling environmental policies, where in consequence is reflected the natural resource.

\section{References}

[1] Costello, C., Kinlan, B., Lester, S. and Gaines, S. (2012) The Economic Value of Rebuilding Fisheries. OECD Food, Agriculture and Fisheries Papers, No. 55, 1-69. 
https://doi.org/10.1787/5k9bfqnmptd2-en

[2] FAO (2003) World Agriculture: Towards 2015/2030 and FAO Perspective. In: Bruinsma, J., Ed., Earthscan Publications Ltd., London. http://www.fao.org/docrep/005/Y4252E/y4252e07.htm\#Ch5

[3] OECD (2012) Rebuilding Fisheries. Inventory of National and Regional Approaches to Fisheries Rebuilding Programmers, 5.

[4] Katzenstein, P. (1976) International Relations and Domestic Structures: Foreign Economic Policies of Advanced Industrial States. International Organization, 30, 1-45. https://doi.org/10.1017/S0020818300003726

[5] Dahl, R. (1957) The Concept of Power. Systems Research and Behavioral Science, 2, 201-215. https://doi.org/10.1002/bs.3830020303

[6] Tucker, R. (1977) The Inequality of Nations. Basic Books, New York, 97.

[7] Holsti, O.R. (2006) Theories of International Relations. Making American Foreign Policy. Taylor and Francis Group, New York, 313-344.

[8] Eur Lex (2014) Maritime Affairs and Fisheries. http://eur-lex.europa.eu/summary/chapter/maritime_affairs_and_fisheries.html?ro ot_default=SUM_1_CODED\%3D02\&locale=en?

[9] Spanish Network of Parks and Clusters (2013) Trend Clusters: Competence + Cooperation, Development in Spain. Madrid.

[10] Dayton-Johnson, J. and Katseli, L. (2006) Migration, Aid and Trade: Policy Coherence for Development. OECD Development Centre Policy Brief, No. 28, 1-32. https://doi.org/10.1787/206328060646

[11] Keohane, R. and Nye, J. (1977) Power and Interdependence: World Politics in Transition. Little Brown, Boston.

[12] Cifuentes, J., Torres, P. and Frías, M. (1997) Ocean and Its Resources. IV Sciences of the Sea: Biological Oceanographic. 2nd Edition, Economic Culture Fund, Mexico, $1-12$.

[13] Nayma, E. (2006) Analysis of the Hispanic-Moroccan Agreements and Its Effects on Economic and Trade Relations between Morocco and Spain (1956-2003). Doctoral Thesis, Economic and Business Faculty, Universidad Autónoma de Madrid, Spain, 17-19.

[14] Mera, T. and Gómez, F. (2001) From Economy and Economic Thought. Tribute to PhD Juan Velarde Fuentes, Universidad Pontifica Comillas Editorial, Madrid, Spain, 184-186.

[15] Martinez D’Meza, H. (1979) Development of Foreign Investment in Mexican Fishing. Proceedings of the Gulf and Caribbean Fisheries Institute, 31, 3-6.

[16] Medina, H. (1976) Fishing Policy. Policies of Industrial, Trade and Fishing Development in Mexico 1971-1976. Journal of Foreign Trade, 26, 57-62.

[17] Doode, S. (1990) The Sardine Fishery in Sonora. Relations, 11, 45-78.

[18] Sosa-Nichizaki, O. (1998) Historic Revision of the Houting Fish Management in the Mexican Pacific. Marine Sciences, 24, 95-111.

[19] Macias, R., Vidaurri-Sotelo, A. and Santana, H. (1994) Analysis of the Capture Trend by Unit Effort in the Sailfish Fishing in the Mexican Pacific. Marine Sciences, 20, 393-408.

[20] Ministry of Foreign Affairs. Foreign Policy (2013) International Treaties Celebrated by Mexico. http://www.sre.gob.mx/tratados/index.php

[21] Inter-American Tropical Tuna Commission (2011) Tuna and Houting Fishes in the 
East Pacific Ocean in 2010. 82th Edition, IATTC Document, 82-05 and 3-31.

[22] Santinelli, J. (2009) Socio-Economic Indicators of the Fishing and Aquaculture Sector. CCEDRSSA, Mexico, 1-98.

[23] Alcalá, G. (2003) Fishing Policies in Mexico (1946-2000): Contradictions and Successes in the National Fishing Planning. Centre of Scientific Investigation and Higher Education of Ensenada, El Colegio de Michoacán, 1-24.

[24] Ministry of the Interior (2012) Treaties in Force Celebrated by Mexico (1836-2012). www.economia-snci.gob.mx/sicait/5.0/

[25] Official Journal of the Federation (1992) Promulgation Decree of the General Treaty of Cooperation and Friendship between the United States of Mexico and the Spanish Kingdom.

http://dof.gob.mx/nota_detalle.php?codigo $=4654154 \&$ fecha $=06 / 03 / 1992$

[26] Carrillo, A. (2004) Mexico and the European Union: A New Strategic Relation. 13.Crónica_legislativa,_No_13,_2000.pdf

[27] Velázquez, R. and Domínguez, R. (2008) Relations Mexico-European Union: A General Evaluation in the Six-Year Rule of the President Vicente Fox. CIDE No. 169, International Studies Division, Mexico, 1-36.

[28] La Crónica (2013) Concern to the Tuna Seizure to Mexico by the USA. http://www.cronica.com.mx/notas/2013/772578.html

[29] WTO (2015) México etc. versus US tuna-dolphin. https://www.wto.org/spanish/tratop_s/envir_s/edis04_s.htm

[30] Sberro, S. (2004) The Free Trade Agreement with the EU Sequel of NAFTA or Strategic Alternative? In: De la Reza Germán, A., Ed., Mexico, beyond NAFTA, Competitiveness and Diversification of Markets, Plaza y Valdés, UAM, Mexico, 204.

[31] El Mundo (2009) Overfishing Leaves Predators like Dolphins and Tuna without Food. http://www.elmundo.es/elmundo/2009/03/02/ciencia/1236013404.html

[32] Official Journal of the European Union (2000) Decision No 2/2000 of the Joint Council CE_Mexico of Arch 23th of 2000.

http://www.economia.gob.mx/files/comunidad_negocios/tlcs/decisiones_consejo_u e/Decision2_2000.pdf

[33] Ministry of Economy (2010) Agreement Announcing the Decision No $1 / 2010$ of the Joint Committee Mexico-EU Regarding Annex III of the Decision No 2/2000 of the Joint Council EU-Mexico of March 23th of 2000, Related to the Definition of the Concept of Origin Products and to the Procedures of Administrative Cooperation. Official Journal of the Federation.

[34] Official Journal of the European Union (2001) Commissions Decision of November 22nd of 2001 That Modifies the Decision 98/695/EC by Which Is Fixed the Particular Conditions of Importation of Fishing and Aquaculture Productos Originating in Mexico. Notified with the Number C.

http://www.bruselas.economia.gob.mx/swb/work/models/bruselas/Resource/1/WE B/marco/CE\%20L307\%20pesca\%20acuicultura\%2024\%20nov\%2001.pdf

[35] Official Journal of the Federation (2000) Second Section: Promulgation Decree of the Agreement of Economic Association, Politic Conciliation and Cooperation between the United States of Mexico and the European Community and Its Member States, the Decision of the Joint Council of This Agreement; and the Decision of the Joint Council of the Domestic Agreement about Trade and Related Issues with Trade between the United States of Mexico and the European Community. http://www.ina.com.mx/documentos/comercio_exterior/acuerdos_comerciales/TL C\%20UE.pdf 
[36] Chamber of Deputies H. Congress of the Union (2000) Free Trade Agreement Mexico-European Union. Studies Unit of Public Finances, 1-55. http://www.cefp.gob.mx/intr/edocumentos/pdf/cefp/cefp0062000.pdf

[37] Silvetti, R. (2001) Free Trade Agreement European Union-Mexico: Guide of Use. $1-15$. http://eeas.europa.eu/delegations/mexico/documents/eu_mexico/guiauso_es.pdf

[38] Bolt, H. (2008) Balance of the Global Agreement between Mexico and the European Union: 8 Years after Its Entry into Force. The Green Policy Foundation, Edited by the Regional Office for Mexico, Central America and the Caribbean of the Heinrich Böll Stiftung. Mexico City.

[39] SAGARPA-MAPA (2002) Cooperation Agreement in Agricultural Matter between the Ministry of Agriculture, Livestock, Rural Development, Fishing and Food of the United States of Mexico and the Ministry of Agriculture, Fishing and Food of the Spanish Kingdom. 1-5.

http://www.conapesca.sagarpa.gob.mx/work/sites/cona/resources/PDFContent/487 9/ESPANA_ANEXO_TEC_PESCA.pdf

[40] Ministry of Agriculture, Food and Environment of Mexico (2012) Understanding Memorandum of Agricultural, Rural, Fishing and Food Matters. Between MAGRAMA and SAGARPA Signed in 2012 Spain-Mexico.

http://www.mapama.gob.es/es/ministerio/funciones-estructura/organizacion-organi smos/ministerio-exterior/americadelnorte/mexico/memorando/default.aspx

[41] European Parliament (2008) The Partnership Agreement in Economy, Political Consensus and Cooperation EU-Mexico. General Direction of the EU Foreign Policies, Information Note PE-405-661, Balance 2007-2008, 1-21.

http://www.europarl.europa.eu/meetdocs/2004_2009/documents/nt/722/722986/72 2986es.pdf

[42] Greenpeace (2014) A Program for the Earth: Social and Environmental Justice to Face the Crisis. The 14 Requests of Environmental Organizations for the European Parliament Elections, 1-7.

http://www.greenpeace.org/espana/Global/espana/2014/Report/general/un_progra ma_por_la_tierra_web.pdf

[43] Este País (2001) Pirate Fishing in Mexico. http://estepais.com/inicio/historicos/122/11_Medio\%20Ambiente_comercio_Green peace_122.pdf

[44] Pearson, F. and Rochester, M. (2000) International Relations. Global Situation in the XXI Century. Inter-American McGraw-Hill Editorial S.A., Bogotá, 13-17 and 304-433. 